\title{
Effect of Deep Drying and Torrefaction Temperature on Proximate, Ultimate Composition, and Heating Value of 2-mm Lodgepole Pine (Pinus contorta) Grind
}

\author{
Jaya Shankar Tumuluru
}

Idaho National Laboratory, 750 University Blvd., Energy Systems Laboratory, PO: Box: 1625, Idaho Falls, ID 83415, USA; jayashankar.tumuluru@inl.gov; Tel.: +1-208-526-0529

Academic Editor: Gou-Jen Wang

Received: 24 April 2016; Accepted: 14 June 2016; Published: 22 June 2016

\begin{abstract}
Deep drying and torrefaction compose a thermal pretreatment method where biomass is heated in the temperature range of $150-300{ }^{\circ} \mathrm{C}$ in an inert or reduced environment. The process parameters, like torrefaction temperature and residence time, have a significant impact on the proximate, ultimate, and energy properties. In this study, torrefaction experiments were conducted on 2-mm ground lodgepole pine (Pinus contorta) using a thermogravimetric analyzer. Both deep drying and torrefaction temperature $\left(160-270{ }^{\circ} \mathrm{C}\right)$ and time (15-120 min) were selected. Torrefied samples were analyzed for the proximate, ultimate, and higher heating value. The results indicate that moisture content decreases with increases in torrefaction temperature and time, where at $270{ }^{\circ} \mathrm{C}$ and $120 \mathrm{~min}$, the moisture content is found to be $1.15 \%$ (w.b.). Volatile content in the lodgepole pine decreased from about $80 \%$ to about $45 \%$, and ash content increased from $0.77 \%$ to about $1.91 \%$ at $270{ }^{\circ} \mathrm{C}$ and $120 \mathrm{~min}$. The hydrogen, oxygen, and sulfur content decreased to $3 \%, 28.24 \%$, and $0.01 \%$, whereas the carbon content and higher heating value increased to $68.86 \%$ and $23.67 \mathrm{MJ} / \mathrm{kg}$ at $270{ }^{\circ} \mathrm{C}$ and $120 \mathrm{~min}$. Elemental ratio of hydrogen to carbon and oxygen to carbon $(\mathrm{H} / \mathrm{C}$ and $\mathrm{O} / \mathrm{C})$ calculated at $270{ }^{\circ} \mathrm{C}$ and a 120 -min residence time were about 0.56 and 0.47 . Based on this study, it can be concluded that higher torrefaction temperatures $\geqslant 230{ }^{\circ} \mathrm{C}$ and residence time $\geqslant 15$ min influence the proximate, ultimate, and energy properties of ground lodgepole pine.
\end{abstract}

Keywords: lodgepole pine; torrefaction; thermogravimetric analysis; proximate and ultimate composition

\section{Introduction}

In the recent United Nations Paris Framework Convention on Climate Change (PFCCC), there is a call to mitigate the global annual emissions of greenhouse gases by 2020 in order to reduce the global average temperature increase to less than $2{ }^{\circ} \mathrm{C}$ [1]. Renewable energies represent a diversity of sources that can help to maintain the equilibrium of different ecosystems. Among these, biomass is considered carbon neutral due to the carbon dioxide released during its conversion that is already part of the carbon cycle [2]. According to the Kyoto Protocol [3], increasing the use of biomass helps to reduce carbon dioxide emissions and to reduce its negative impact on the environment. According to the U.S. Department of Energy (DOE) [4], about a billion tons of biomass is available in the United States for energy applications. This enhances the ability of the United States to include biomass as a sustainable and significant part of domestic energy production.

\subsection{Biomass Limitations for Solid and Liquid Fuel Applications}

Energy from biomass can be produced using thermochemical (direct combustion, gasification, and pyrolysis), biological (anaerobic digestion and fermentation), and chemical (esterification) technologies. 
Out of all of these technologies, combustion of biomass can provide a direct near-term energy solution. The inherent physical (particle size and density) and chemical characteristics (proximate, ultimate, and energy properties) of raw biomass restrict its use in higher percentages for direct-combustion applications. Furthermore, grinding raw biomass with high moisture content is very challenging due to its fibrous nature. The study of Tumuluru et al. [5] indicated that high moisture in biomass increases the grinding energy and negatively impacts the particle size distribution. Additionally, higher moisture in the biomass will result in plugging the grinder screens and the reactor and bridging of the particles in the conveyors. In terms of chemical composition, the raw biomass has a higher oxygen and hydrogen content and a lower carbon and calorific value as compared to fossil fuels [6]. All of these limitations do not make biomass a great candidate for production of solid and liquid biofuels. In their studies, Tumuluru et al. [7] researched the impact of feedstock supply system unit operations and the effects on feedstock quality and cost. The same authors suggested that new harvesting methods and mechanical, chemical, thermal pretreatment technologies will help to improve the biomass physical and chemical properties. These improvements will make biomass meet the specifications in terms of density, particle size, ash composition, and carbohydrate content for both biochemical and thermochemical conversion applications. Various thermal methods, such as dry and wet torrefaction (hydrothermal carbonization) and steam explosion, as well as chemical pretreatment techniques, such as ionic, acid, alkali, and ammonia fiber expansion, were investigated to understand how they improve the biomass specifications for biofuels production [8-13]. Recent studies by Sarkar et al. [14] and Yang et al. [15] on using torrefied and torrefied-densified switchgrass for both gasification and pyrolysis applications have indicated that higher quality syngas and bio-oil are produced when compared to the ones produced using raw switchgrass. In their studies, Hoover et al. [16], Ray et al. [17], and Aston et al. [18] indicate that chemical pretreatments (i.e., ammonia fiber expansion (AFEX), acid, and alkali) and further densification help to increase the liquid fuels production through biochemical conversion.

\subsection{Dry Torrefaction}

Dry torrefaction is a thermal pretreatment technique that is used to improve the physical and chemical properties of biomass. Torrefaction is defined as slowly heating the biomass in an inert atmosphere to a maximum temperature of $300^{\circ} \mathrm{C}[19,20]$, which will result in a solid uniform product with lower moisture and higher energy content when compared to raw biomass. Various biomass reactions occur during torrefaction, such as devolatilization and carbonization of hemicellulose, depolymerization and devolatilization/softening of lignin and depolymerization, and devolatilization of cellulose. These reactions result in changes in biomass moisture, chemical composition, and energy content. The feedstock and process variables that influence the torrefaction process are (1) feedstock type, (2) particle size, (3) temperature, (4) residence time, and (5) heating rate [13]. Figure 1 indicates the change in the biomass components at different temperature regimes [13].

Tumuluru et al. [13] divide thermal pretreatment regimes into three zones: non-reactive $50-150{ }^{\circ} \mathrm{C}$, reactive $150-200^{\circ} \mathrm{C}$, and destructive drying 200-300 ${ }^{\circ} \mathrm{C}$. According to Tumuluru and Hess [21] and Tumuluru et al. [13], the reactive drying temperature regime is also called deep drying, whereas the destructive drying temperature is called the torrefaction regime. The initial heating of biomass up to $150^{\circ} \mathrm{C}$ (non-reactive drying zone) removes the unbound water. Increasing the temperature from 150-200 ${ }^{\circ} \mathrm{C}$ removes most of the bound water by a thermo-condensation process [22]. Furthermore, increasing the temperature to $>200{ }^{\circ} \mathrm{C}$ will result in decomposition, devolatilization, and carbonization reactions. Most of the biomass hemicellulose undergoes decomposition reactions, which result in significant changes in color, chemical composition, and physical characteristics. At temperatures $>280{ }^{\circ} \mathrm{C}$, the process is completely exothermic, which results in significant increases in the production of $\mathrm{CO}_{2}$, phenols, acetic acid, and other higher hydrocarbons. During torrefaction, hemicellulose degradation causes the destruction of $\mathrm{OH}$ functional groups and will leave the material hydrophobic. The degree of hydrophobicity depends on the torrefaction temperature. Hydrophobicity will help 
biomass to absorb less moisture during its storage in different environments, therefore making it more stable against fungal and microbial attacks.

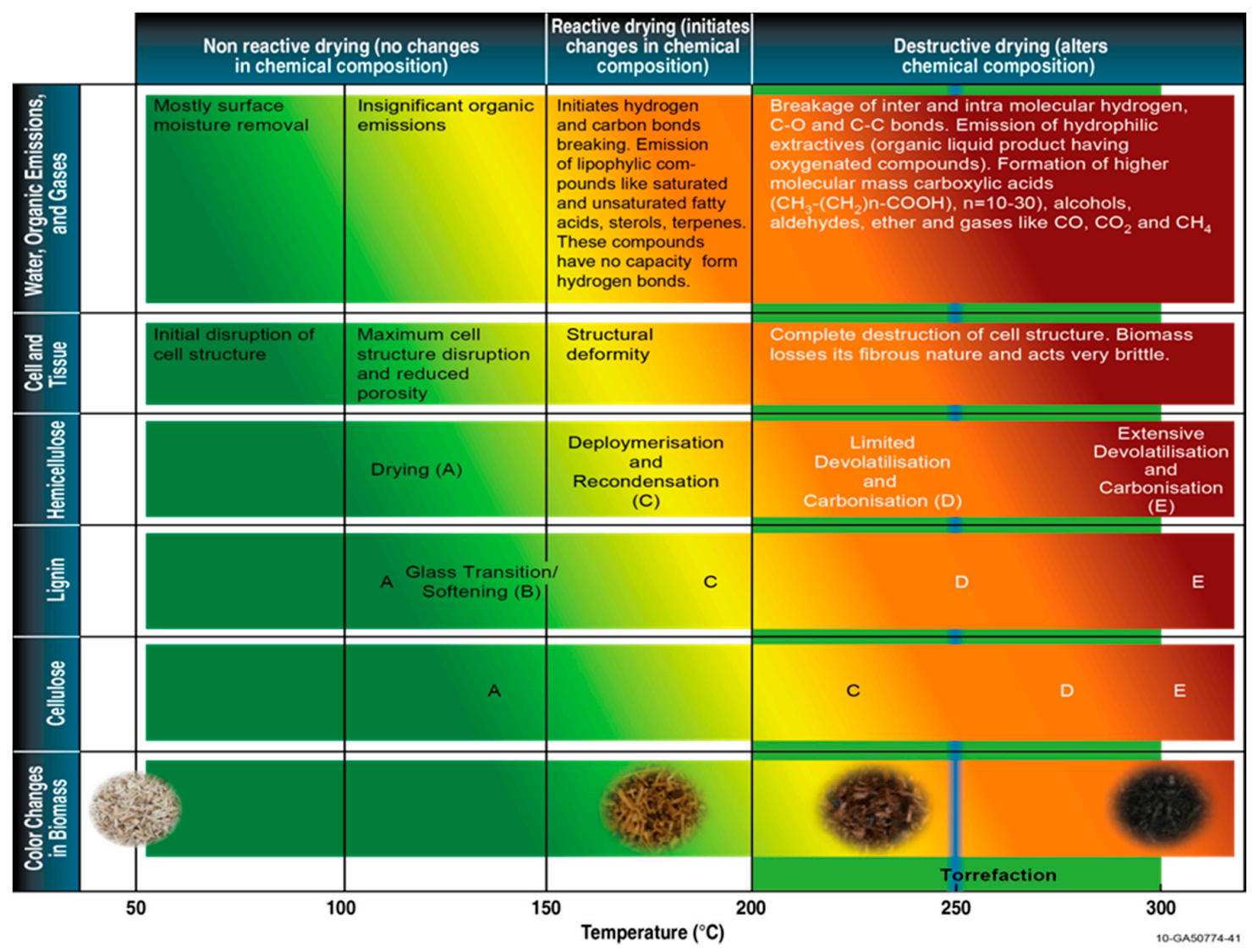

Figure 1. Non-reactive, reactive, and destructive drying temperature impact on the biomass components (adapted from [13]).

\subsection{Deep Drying and Torrefaction Parameters}

The biomass parameters commonly used in deep drying and torrefaction are reaction temperatures of $160-300{ }^{\circ} \mathrm{C}$, heating rates of $<50{ }^{\circ} \mathrm{C} / \mathrm{min}$, and residence times $<30 \mathrm{~min}$ [13]. The absence or limiting of oxygen presence to $<7 \%$ in the reactor by avoiding oxidation and auto-ignition during its heating is of great importance. Many researchers have worked on the torrefaction of agricultural and woody biomass using a thermogravimetric analyzer (TGA) $[6,23,24]$. These researchers have successfully used TGA, on both woody and herbaceous biomass, to understand the effect of temperature and residence time on torrefaction kinetics and the chemical, proximate, and energy properties. Tumuluru [6] studied torrefaction of corn stover and switchgrass using TGA, concluding that the torrefaction temperature has the most significant effect compared to residence time on the chemical and energy properties.

\subsection{Objectives}

In the past several decades, lodgepole pine (Pinus contorta) has gained much importance due to its high quality timber and yields [25]. This is the third largest timber type in the Western United States after ponderosa pine and Douglas fir. Lodgepole pine is available in larger quantities, which leads to a growing interest in its suitability as a feedstock for bioenergy applications [25-27]. In the present study, lodgepole pine was selected to understand the changes torrefaction can bring in terms of the proximate, ultimate, and energy properties. In the present research, a smaller particle size of $2 \mathrm{~mm}$ was selected to conduct the torrefaction studies. Studies conducted by Bridgewater et al. [28] indicate that for efficient thermo-chemical conversion, such as pyrolysis, particle sizes of approximately 2-mm 
are necessary. In general, bigger particle sizes result in secondary reactions, leading to the formation of more tars, whereas smaller particle sizes due to less time in the reaction zone result in minimizing the secondary reactions and, in turn, result in less tar formation.

The overall objective of this work is to conduct thermal pretreatment studies (deep drying and torrefaction) over a wide range of temperatures and residence times using the TGA. The specific objectives of this study are (1) to understand the effect of deep drying and torrefaction temperature in the range of $160-270{ }^{\circ} \mathrm{C}$ and a residence time of $15-120 \mathrm{~min}$ on the proximate composition (i.e., moisture content, volatile content, fixed carbon content, and ash content), the ultimate composition (i.e., carbon, hydrogen, sulfur, nitrogen, oxygen, and $\mathrm{H} / \mathrm{C}$ and $\mathrm{O} / \mathrm{C}$ ratios), and the higher heating value of a 2-mm lodgepole pine grind; (2) to understand the significance of the torrefaction temperature and the residence time with respect to the ultimate composition, proximate composition, and higher heating values; and (3) to develop linear regression models for the torrefaction parameters with respect to the proximate composition, ultimate composition, and higher heating values.

\section{Materials and Methods}

Clean lodgepole pine (Pinus contorta) wood chips were used in the present study. The wood chips were dried to $<5 \%$ (w.b.) moisture content in a laboratory oven and were further ground in a Willey mill fitted with a 2-mm screen. The ground samples were double bagged, stored in an air-tight container, and used to conduct the torrefaction tests.

\subsection{Torrefaction Studies Using the Thermogravimetric Analyzer}

Deep drying and torrefaction studies on ground lodgepole pine was carried out using TGA (Figure 2). The LECO (Model No: TG 701) TGA was used to conduct the torrefaction tests. A $\mathrm{N}_{2}$ atmosphere was used in this study. A method file was developed to carry out the torrefaction studies using TGA [24]. TGA also measures mass loss as total moisture, ash, volatile content, or loss-on-ignition. The LECO C/H/N analyzer was used for estimating the carbon, hydrogen, and nitrogen of the raw and torrefied samples. The American Society for Testing and Materials (ASTM standard) methods were used for estimating the chemical composition (Table 1). The higher heating values of raw and torrefied samples were measured using a bomb calorimeter. The reported chemical composition and energy property are an average of three measurements. Experiments were conducted in a temperature range of $160-270{ }^{\circ} \mathrm{C}$ and residence times of $15-120 \mathrm{~min}$. Table 2 indicates the experimental design followed for conducting deep drying and torrefaction studies.

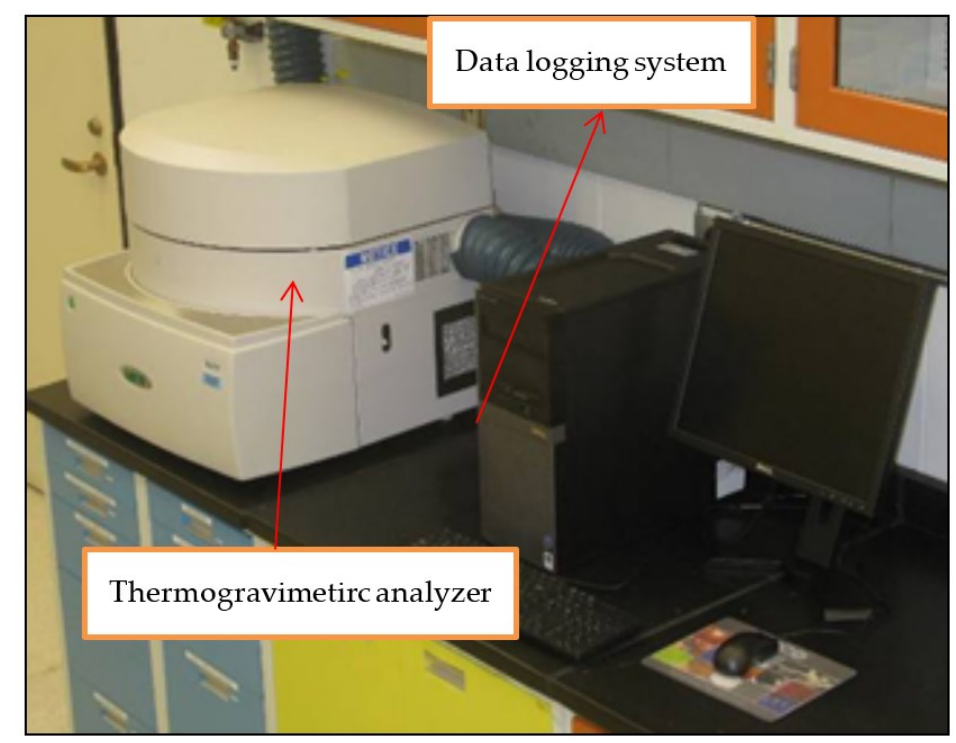

Figure 2. LECO Model 701 thermogravimetric analyzer [6]. 
Table 1. Methods to measure the chemical properties and higher heating values.

\begin{tabular}{|c|c|c|}
\hline \multirow{2}{*}{ S. No. } & Chemical Composition & \multirow{2}{*}{ Procedure } \\
\hline & Proximate & \\
\hline 1 & Moisture & ASTM D3173 [29] \\
\hline 2 & Ash & ASTM D 3174 [30] \\
\hline 3 & Volatiles & ASTM D3175 [31] \\
\hline 4 & Fixed carbon & Fixed carbon calculated by the difference method \\
\hline \multicolumn{2}{|r|}{ Ultimate Composition } & \\
\hline 1 & Moisture & ASTM D3173 [29] \\
\hline 2 & Carbon & ASTM D3178 [32] \\
\hline 3 & Hydrogen & ASTM D3178 [32] \\
\hline 4 & Nitrogen & ASTM D3179 [33] \\
\hline 5 & Sulphur & ASTM D3177 [34] \\
\hline 7 & Oxygen & Oxygen calculated by the difference method \\
\hline 8 & $\mathrm{H} / \mathrm{C}$ ratio & $\mathrm{H} / \mathrm{C}$ : number of hydrogen atoms/number of carbon atoms $=(\% \mathrm{H} / 1) /(\% \mathrm{C} / 12)$ \\
\hline 9 & $\mathrm{O} / \mathrm{C}$ ratio & $\mathrm{O} / \mathrm{C}$ : number of oxygen atoms $/$ number of carbon atoms $=(\% \mathrm{O} / 8) /(\% \mathrm{C} / 12)$ \\
\hline 6 & Higher heating value (HHV) & ASTM D5865 [35] \\
\hline
\end{tabular}

Table 2. Experimental design for the deep drying and torrefaction experiments.

\begin{tabular}{ccccc}
\hline Process & Temperatures $\left({ }^{\circ} \mathbf{C}\right)$ & Residence Time $($ min) & Particle Size $(\mathbf{m m})$ & Heating Rate $\left({ }^{\circ} \mathbf{C} /\right.$ min) \\
\hline Deep drying & 160,180 & $15,30,60$, and 120 & 2 & 10 \\
Torrefaction & 230,270 & $15,30,60$, and 120 & 2 & 10 \\
\hline
\end{tabular}

\subsection{Data Analysis: Analysis of Variance and Multiple Regression Analysis}

The experimental data on the proximate composition, ultimate composition, and higher heating values obtained at different torrefaction temperatures $\left(160,180,230\right.$ and $\left.270{ }^{\circ} \mathrm{C}\right)$ and residence times $(15,30,60$ and $120 \mathrm{~min})$ for a 2-mm lodgepole pine grind were used to draw the linear plots, develop multiple regression models, (Equation 1), and understand the significance of the torrefaction process variables with respect to chemical properties that were studied. Dell Statistica (Version 10) statistical software was used to develop the multiple regression models and analysis of variance (ANOVA) of the experimental data. The coefficient of determination was used to determine the model fit.

$$
f(y)=b_{0}+b_{1} x_{1}+b_{2} x_{2}
$$

where:

$$
\mathrm{b}_{0}, \mathrm{~b}_{1} \text { and } \mathrm{b}_{2}=\text { equation constants }
$$

$\mathrm{x}_{1}$ and $\mathrm{x}_{2}=$ torrefaction temperature and torrefaction residence time

\section{Results}

Figure 3 indicates the ground lodgepole pine samples that were torrefied at different temperatures and residence times. It is clear from the figure that when increasing the torrefaction temperature, the color of the biomass changes from brown to black. Tumuluru et al. [13] report that the biomass turns brown to black at $150-300^{\circ} \mathrm{C}$. This can be mainly attributed to the chemical compositional changes that occur in the biomass components, such as hemicellulose, lignin, and cellulose. The major reactions that change the biomass color are devolatilization and carbonization of hemicellulose, depolymerization and devolatilization/softening of lignin, and depolymerization and devolatilization of cellulose. Food industries use color as an indicator to understand the quality changes in products. For example, in a coffee-bean roasting process, the change in color is used as an indicator to define the degree of roasting. The chemical compositional changes are due to the breakage of hydrogen and carbon bonds. The disruption of most inter- and intra-molecular hydrogen bonds, $\mathrm{C}-\mathrm{C}$ and $\mathrm{C}-\mathrm{O}$ bonds, results in the formation of hydrophilic extractives, carboxylic acids, alcohols, aldehydes, ether, and gases (e.g., CO, $\mathrm{CO}_{2}$, and $\mathrm{CH}_{4}$ ). All of these chemical compositional changes within the biomass will significantly change its color. Branca et al. [36] indicate that the color of the wood chips changes when the biomass 
is torrefied at different temperatures and residence times. Nhuchhen et al. [37] observed a similar color change, where higher torrefaction temperatures resulted in a dark black product.

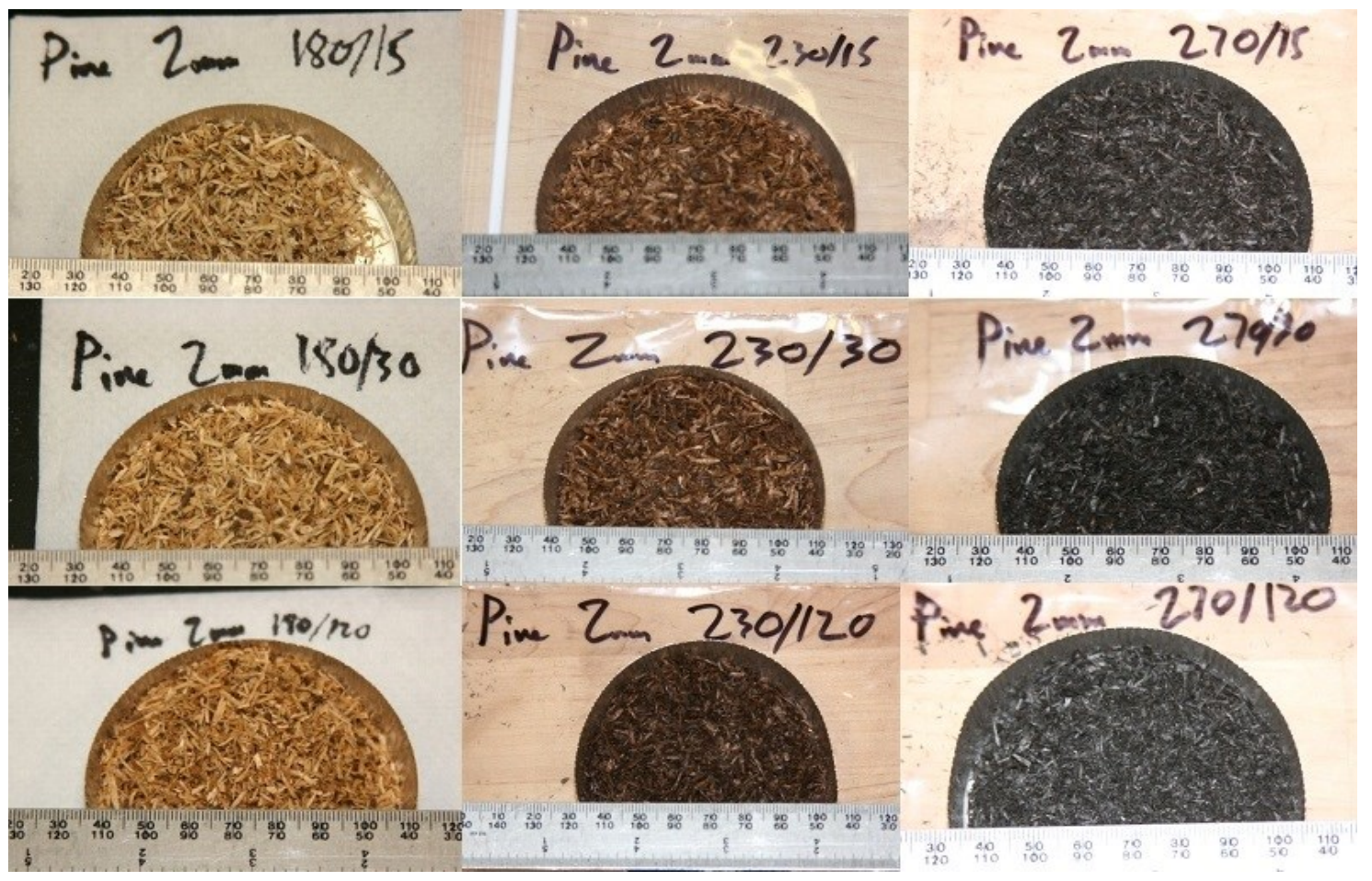

Figure 3. Color changes in torrefied lodgepole pine grind at different torrefaction temperatures and residence times.

\subsection{Proximate, Ultimate Composition and Higher Heating Values}

Proximate-composition measurement includes moisture content, volatiles' content, ash content, and fixed carbon, whereas fixed carbon is calculated based on the difference. The ultimate composition includes carbon, hydrogen, nitrogen, sulfur, and oxygen and the oxygen content is calculated by the difference method. The proximate, ultimate, and higher heating values of the 2-mm raw lodgepole pine grind are shown in Table 3.

Table 3. Proximate, ultimate, and higher heating values of the 2-mm lodgepole pine grind.

\begin{tabular}{ccc}
\hline & Chemical Composition & \\
\cline { 2 - 2 } S. No. & Proximate \\
& Moisture & 4.2 \\
1 & Ash & 0.69 \\
2 & Volatiles & 80.23 \\
3 & Fixed carbon & 15.1 \\
4 & Ultimate composition & \\
& Carbon & 52.23 \\
1 & Hydrogen & 6.2 \\
2 & Nitrogen & 0.47 \\
3 & Sulphur & 0.022 \\
4 & Oxygen & 41.23 \\
5 & H/C & 1.42 \\
6 & O/C & 0.59 \\
7 & Higher heating value (HHV) & 19.37 \\
8 & & \\
\hline
\end{tabular}




\subsection{Moisture Content}

The initial moisture content of the 2-mm lodgepole pine grind was about $4.2 \%$ (w.b.). After torrefaction, the torrefied samples' moisture content had significantly decreased with the increase in torrefaction temperature and time. The lowest moisture content observed was about $1.15 \%$ (w.b.) at $270{ }^{\circ} \mathrm{C}$ and a 120-min residence time (Figure 4). The percent decrease observed in moisture content was about $23.09 \%$ from the initial value of about $4.2 \%$ (w.b.) to $3.23 \%$ (w.b.) at $160{ }^{\circ} \mathrm{C}$ for $15 \mathrm{~min}$. Increasing the torrefaction temperature and time to $270{ }^{\circ} \mathrm{C}$ and $120 \mathrm{~min}$, the moisture content of the samples reduced by about $72.61 \%$ from the initial value of $4.2 \%$. The decrease in moisture content from $160,180,230$ and $270{ }^{\circ} \mathrm{C}$ and a 30-min residence time was about $29.04 \%, 43.80 \%, 56.90 \%$ and $68.57 \%$. A similar decrease in moisture content was observed at other residence times, as well.

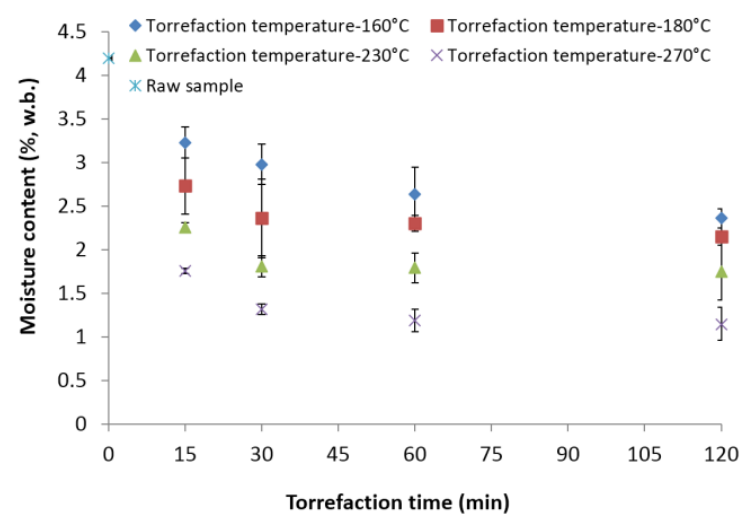

Figure 4. Moisture content in the lodgepole pine grind with respect to the torrefaction temperature and time.

\subsection{Volatile Content}

At lower torrefaction temperatures $\left(160\right.$ and $\left.180^{\circ} \mathrm{C}\right)$ and different residence times, the decrease in volatile content in the torrefied biomass was relatively minimal (the maximum decrease was about $1.3 \%$ and $3.72 \%$ at $120 \mathrm{~min}$ with respect to the original value) (Figure 5). Increasing the torrefaction temperature to 230 and $270{ }^{\circ} \mathrm{C}$ and its residence time to $120 \mathrm{~min}$ reduced the volatile content to about $75.41 \%$ and $55.28 \%$ compared to its original value. The effect of torrefaction temperature showed a more significant effect when compared to the residence time. Carter et al. [38] reported similar volatile content $(76.37 \%$ and $56.53 \%)$ in the lodgepole pine samples when torrefied at 225 and $275{ }^{\circ} \mathrm{C}$ for a 30-min residence time.

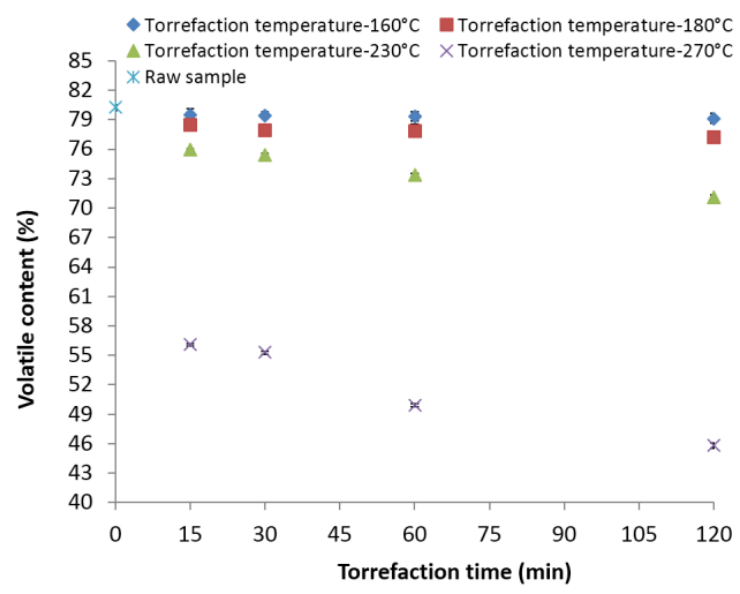

Figure 5. Volatile content in the lodgepole pine grind with respect to the torrefaction temperature and time. 


\subsection{Ash Content}

The ash content in the torrefied material increased with the increase of torrefaction temperature and time (Figure 6). The changes in the ash content are mainly due to breakdown of carbon-hydrogen bonds, resulting volatile loss and further concentrating the ash content in the biomass. The highest ash content of about $1.91 \%$ was observed for samples torrefied at $270{ }^{\circ} \mathrm{C}$ and $120 \mathrm{~min}$. The increase was about $176 \%$ with respect to the original value. The increase in relative ash content at different torrefaction temperatures $\left(160,180,230\right.$ and $270{ }^{\circ} \mathrm{C}$ ) and a 30-min residence time was $36.9 \%, 46.37 \%$, $102.01 \%$ and $134.78 \%$ compared to its initial value of $0.69 \%$.

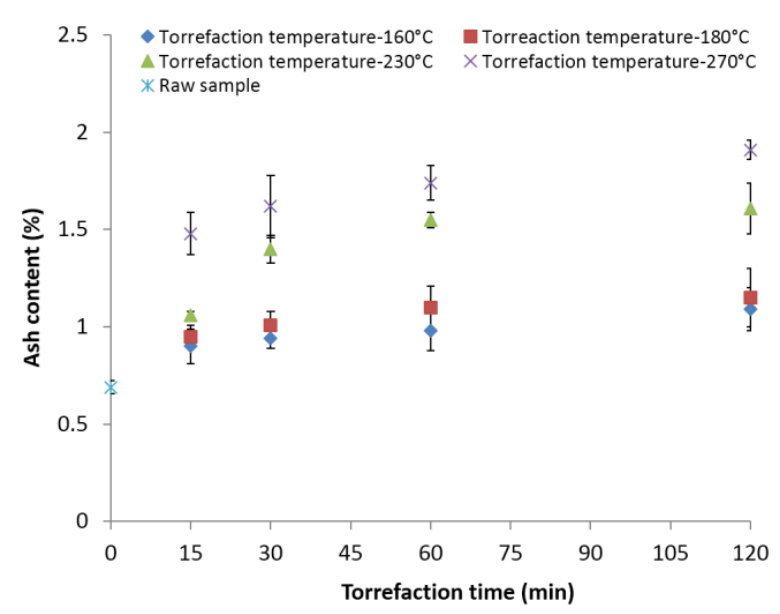

Figure 6. Ash content in the lodgepole pine grind with respect to the torrefaction temperature and time.

\subsection{Fixed Carbon}

Figure 7 indicates the changes in the fixed carbon content in the ground lodgepole pine torrefied at different temperatures and residence times. The initial fixed carbon of the raw biomass was $15.91 \%$. Increasing the temperature to $160,180,230$ and $270{ }^{\circ} \mathrm{C}$ and a 30-min residence time increased the fixed carbon content to about $18.43 \%, 18.79 \%, 22.34 \%$ and $41.01 \%$ (an increase of $15.83 \%, 18.01 \%, 40.41 \%$, and $157.76 \%$ from its original value). The maximum fixed carbon observed at $270{ }^{\circ} \mathrm{C}$ and $120 \mathrm{~min}$ was about $50.48 \%$ (Figure 7). Fixed carbon content data matched closely with the data presented by Carter et al. [38], where at 225 and $275{ }^{\circ} \mathrm{C}$ for $30 \mathrm{~min}$, the observed values were $22.75 \%$ and $42.49 \%$ for lodgepole pine. The results indicate that the increase is marginal at 160 and $180^{\circ} \mathrm{C}$ at all residence times, but further increasing the temperature to 230 and $270{ }^{\circ} \mathrm{C}$ significantly increased the fixed carbon content.

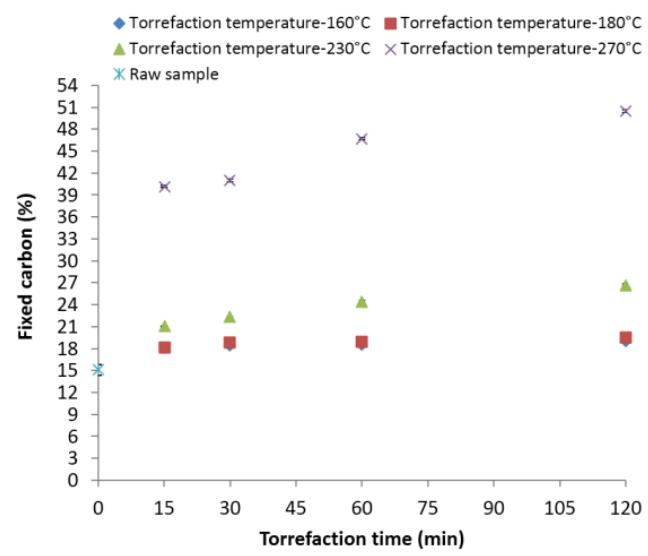

Figure 7. Fixed carbon content in the lodgepole pine grind with respect to the torrefaction temperature and time. 


\subsection{Ultimate Composition}

Ultimate composition measurements include elemental carbon, hydrogen, sulfur, nitrogen, and oxygen by different methods. The ultimate composition of the $2-\mathrm{mm}$ ground lodgepole pine raw material is $6.2 \%$ hydrogen, $52.3 \%$ carbon, $0.28 \%$ nitrogen, $0.02 \%$ sulfur, and $41.23 \%$ oxygen.

\subsection{Carbon (\%)}

The initial elemental carbon in the 2-mm ground lodgepole pine sample was about $52.23 \%$. Heating the biomass at 160 and $180^{\circ} \mathrm{C}$ for a 30-min residence time increased the elemental carbon content to about $56 \%-57 \%$ (Figure 8). Further, increasing the temperature and time to 230 and $270{ }^{\circ} \mathrm{C}$ for $120 \mathrm{~min}$ increased the carbon content to about $62 \%$ and $68 \%$. It is clear from the data that the increase in elemental carbon is significantly higher at temperatures $\geqslant 230{ }^{\circ} \mathrm{C}$. It is also clear from the data that the increase in elemental carbon with the increase in residence time (from 15 to $120 \mathrm{~min}$ ) is about $3 \%$, whereas increasing the torrefaction temperature from 230 to $270{ }^{\circ} \mathrm{C}$ resulted in about an $8 \%$ rise for the residence times studied. Carter et al. [38] reports similar values of carbon content $(64.17 \%)$ for pine when torrefied at $275^{\circ} \mathrm{C}$ and a 30-min residence time.

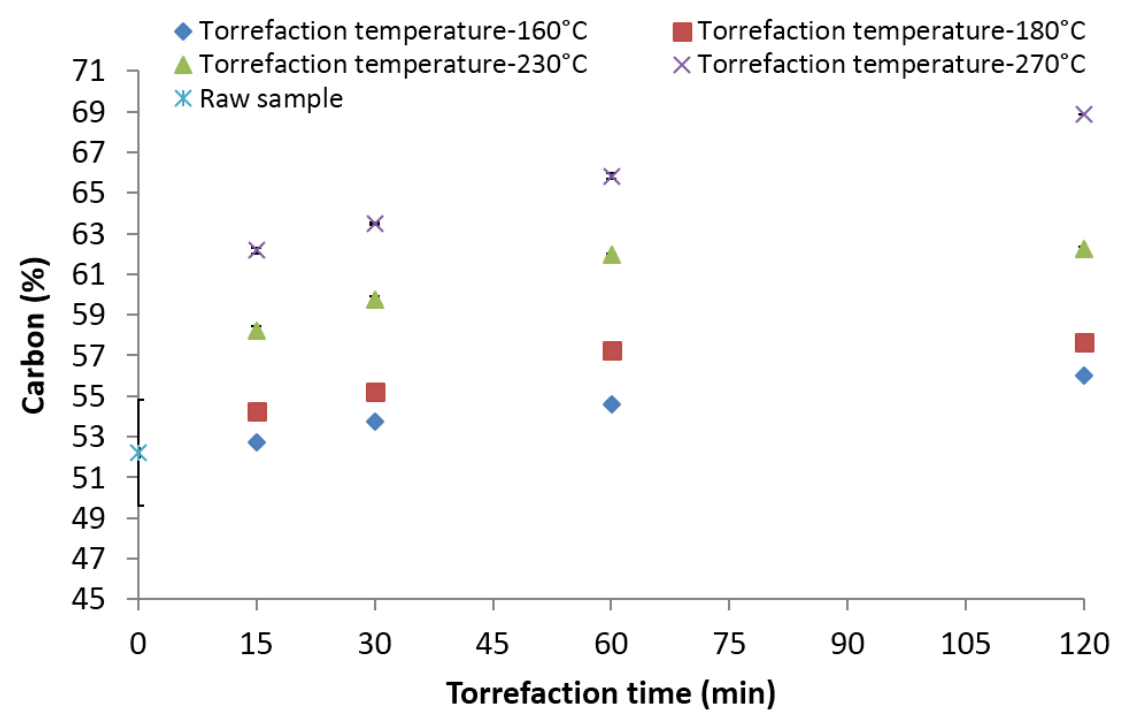

Figure 8. Carbon content in the lodgepole pine grind with respect to the torrefaction time and temperature.

\subsection{Hydrogen (\%)}

The hydrogen content of the raw biomass samples observed was about $6.2 \%$. The decrease in hydrogen content at 160 and $180^{\circ} \mathrm{C}$ for different residence times was marginal, where a maximum decrease of about $5.85 \%$ was observed at $180^{\circ} \mathrm{C}$ and $120 \mathrm{~min}$ (Figure 9). Increasing the torrefaction temperature and residence time to 230 and $120 \mathrm{~min}$ reduced the hydrogen content to about 5.54 and $3 \%$, respectively. The results indicate that the decrease is more significant at higher temperatures of $>230^{\circ} \mathrm{C}$. Furthermore, the data from the present study indicate that higher torrefaction temperatures and residence times played a major role in reducing the hydrogen content. At $270{ }^{\circ} \mathrm{C}$ and a $15-\mathrm{min}$ residence time, the hydrogen content observed was $4.5 \%$, whereas at a 120 -min residence time, the final hydrogen content observed is about $3 \%$ at $270{ }^{\circ} \mathrm{C}$. Carter et al. [38] observed similar trends where hydrogen was about $4.81 \%$ at $275^{\circ} \mathrm{C}$ and $30 \mathrm{~min}$; further increasing the time to $45 \mathrm{~min}$ reduced the hydrogen content to $3.47 \%$. 


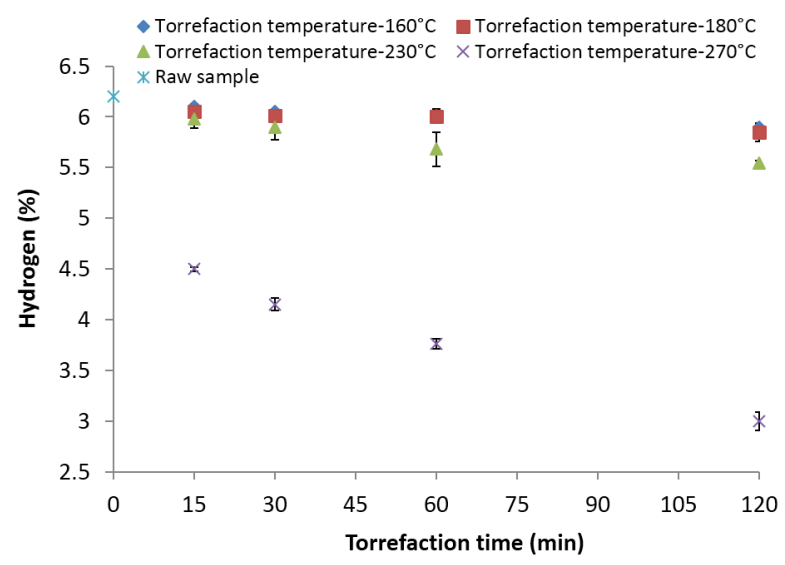

Figure 9. Hydrogen content in the lodgepole pine grind with respect to the torrefaction time and temperature.

\subsection{Oxygen (\%)}

The oxygen content of the raw and torrefied samples was calculated based on the difference method. The initial oxygen content of the raw samples observed was $41.23 \%$. At 160 and $180{ }^{\circ} \mathrm{C}$, the oxygen content observed in the samples was in the range of $40.93 \%-37.04 \%$, whereas at $230{ }^{\circ} \mathrm{C}$, the oxygen content reduced to about $31.14 \%$ (a decrease of about $24.47 \%$ from the initial value). Further increasing the torrefaction temperature to $270{ }^{\circ} \mathrm{C}$ and the residence time to $120 \mathrm{~min}$ decreased the oxygen content in the sample to about $28.24 \%$ (a decrease of about $32 \%$ from the initial value). The data presented by Carter et al. [38] for oxygen content in the pine samples when torrefied at $275{ }^{\circ} \mathrm{C}$ for a 30 -min residence time was $29.27 \%$, which matched closely with the values reported in this research (32.24\%). At 160, 180, 230, and $270{ }^{\circ} \mathrm{C}$ and a 30-min residence time, the observed oxygen values were $40.24 \%, 38.49 \%, 34.21 \%$ and $32.24 \%$ (Figure 10 ). The results indicate that torrefaction temperature had a higher impact on the oxygen content compared to the residence time.

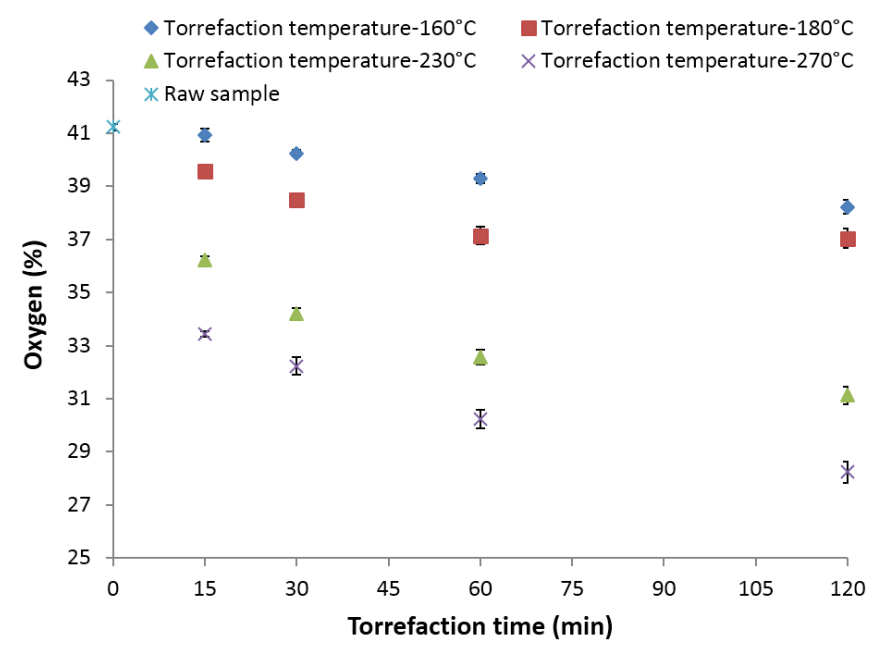

Figure 10. Oxygen content in the lodgepole pine grind with respect to the torrefaction time and temperature.

\subsection{Nitrogen and Sulfur (\%)}

The initial nitrogen and sulfur content observed for the raw biomass samples was $0.47 \%$ and $0.02 \%$. At lower temperatures of 160 and $180^{\circ} \mathrm{C}$ and different residence times, the changes in nitrogen and sulfur content were marginal; however, increasing the torrefaction temperature to 230 and $270{ }^{\circ} \mathrm{C}$ 
at $30 \mathrm{~min}$ decreased the nitrogen and sulfur content to $0.25 \%$ and $0.015 \%$. Furthermore, increasing the residence time to $120 \mathrm{~min}$ decreased the nitrogen and sulfur content to final values of $0.17 \%$ and $0.01 \%$.

\subsection{1. $\mathrm{H} / \mathrm{C}$ and $\mathrm{O} / \mathrm{C}$ Ratios}

The initial hydrogen to carbon $(\mathrm{H} / \mathrm{C})$ and oxygen to carbon $(\mathrm{O} / \mathrm{C})$ ratios of the lodgepole pine sample were 1.42 and 0.59 . The $\mathrm{H} / \mathrm{C}$ ratio decreased when the torrefaction temperature and residence time was increased. The lowest $\mathrm{H} / \mathrm{C}$ and $\mathrm{O} / \mathrm{C}$ ratios observed were 0.56 and 0.47 at a torrefaction temperature of $270{ }^{\circ} \mathrm{C}$ and a 120-min residence time (Figure 11). At 160 and $180^{\circ} \mathrm{C}$ and a 30-min residence time, the $\mathrm{H} / \mathrm{C}$ ratio was about 1.31 and 1.28 and the $\mathrm{O} / \mathrm{C}$ ratio was about 0.99 and 0.69 . Increasing the torrefaction temperature to 230 and $270{ }^{\circ} \mathrm{C}$ and the residence time to 30 min decreased the $\mathrm{H} / \mathrm{C}$ ratio to 1.19 and 0.88 and the $\mathrm{O} / \mathrm{C}$ ratio to near 0.70 and 0.41 . Further increasing the residence time to $120 \mathrm{~min}$ at the same temperature decreased the $\mathrm{H} / \mathrm{C}$ and $\mathrm{O} / \mathrm{C}$ ratios. The change in the $\mathrm{O} / \mathrm{C}$ ratio with respect to the torrefaction temperature is more significant than the torrefaction residence time.

\subsection{2. van Krevelen Diagram}

The van Krevelen diagram was drawn for the $\mathrm{O} / \mathrm{C}$ and $\mathrm{H} / \mathrm{C}$ ratios, for the raw and torrefied ground lodgepole pine, and is compared to different grades of commercially available coals (Central Appalachian, Illinois Basin, Powder River Basin) (Figure 11). According to this plot, torrefaction of ground lodgepole pine shifts the elemental ratios of $\mathrm{H} / \mathrm{C}$ and $\mathrm{O} / \mathrm{C}(0.78$ and 0.36$)$ closer to the commercially available coals, such as Illinois Basin and Powder River Basin coals. Figure 11 indicates that the high-quality coals have a lower ratio of $\mathrm{H} / \mathrm{C}$ to $\mathrm{O} / \mathrm{C}$ (mainly due to the lower oxygen content and higher carbon content) compared to the ground lodgepole pine. Torrefaction of lodgepole pine at 160,180 and $230{ }^{\circ} \mathrm{C}$ at different residence times advanced the $\mathrm{H} / \mathrm{C}$ and $\mathrm{O} / \mathrm{C}$ ratios closer to the commercial coals. At a $270{ }^{\circ} \mathrm{C}$ torrefaction temperature and a 15-120-min residence time, the ground lodgepole pine moved close to Power River Basin and Illinois Basin coal. There was a major shift in the $\mathrm{H} / \mathrm{C}$ and $\mathrm{O} / \mathrm{C}$ values from 230 to $270{ }^{\circ} \mathrm{C}$ (Figure 11). The shift is mostly due to the significant increase in carbon content and the steep decrease in oxygen and hydrogen content. The breakage of inter- and intra-molecular hydrogen and carbon-oxygen and carbon-carbon bonds result in the emission of extractives and oxygenated compounds, which might have resulted in the major shift in the $\mathrm{H} / \mathrm{C}$ and $\mathrm{O} / \mathrm{C}$ values. Additionally, Dutta [39] reports similar elemental ratios of the $\mathrm{H} / \mathrm{C}$ and $\mathrm{O} / \mathrm{C}$ ratio values when pine was torrefied at a higher temperature of $270{ }^{\circ} \mathrm{C}$ and a $30-\mathrm{min}$ residence time.

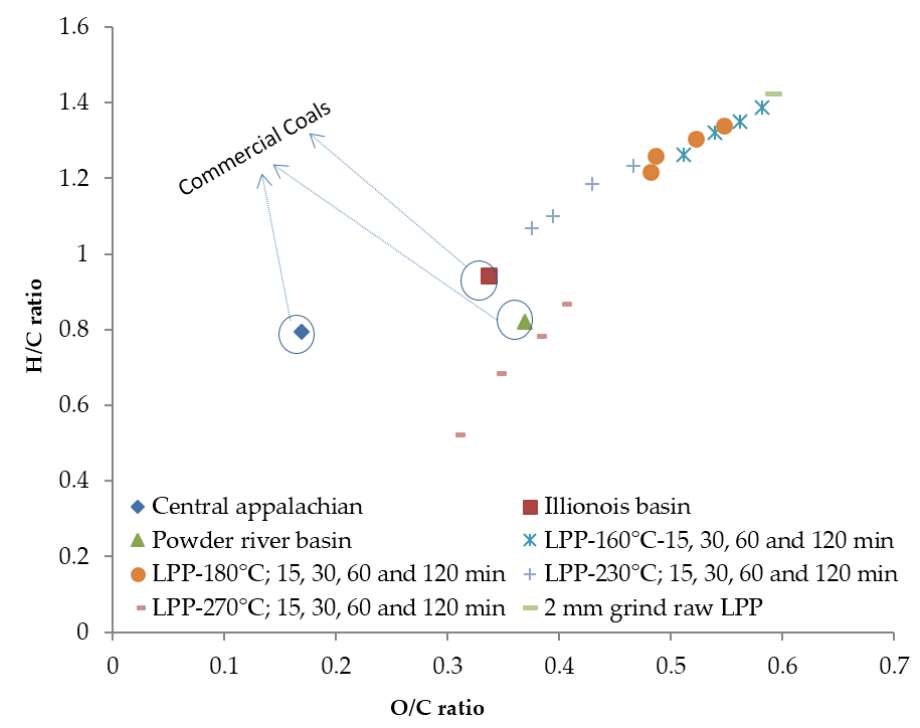

Figure 11. van Krevelen diagram for the raw, torrefied lodgepole pine grind, and the commercial coals. 


\subsection{Higher Heating Value (MJ/kg)}

The initial higher heating value observed for the 2-mm ground lodgepole pine was $19.45 \mathrm{MJ} / \mathrm{kg}$. Increasing the torrefaction temperature to $270{ }^{\circ} \mathrm{C}$ and the time to $30 \mathrm{~min}$ significantly increased the heating value to about $23.67 \mathrm{MJ} / \mathrm{kg}$ (Figure 12). At lower temperatures of 160 and $180^{\circ} \mathrm{C}$ and a 120-min residence time, the heating value increase was found to be marginal (there is about a $1 \mathrm{MJ} / \mathrm{kg}$ increment). Increasing the torrefaction temperature from 180 to $230^{\circ} \mathrm{C}$ for residence times of about $30 \mathrm{~min}$, the increase was about $2 \mathrm{MJ} / \mathrm{kg}(21.34 \mathrm{MJ} / \mathrm{kg})$, whereas at $270{ }^{\circ} \mathrm{C}$, the increase was about $4 \mathrm{MJ} / \mathrm{kg}(23.21 \mathrm{MJ} / \mathrm{kg})$ compared to the higher heating value of raw lodgepole pine grind. The maximum higher heating value observed at $270{ }^{\circ} \mathrm{C}$ and a $120-\mathrm{min}$ residence time was about $21.57 \mathrm{MJ} / \mathrm{kg}$. Peng et al. [40] report that torrefying lodgepole pine at 250 and $300{ }^{\circ} \mathrm{C}$ at $30 \mathrm{~min}$ results in higher heating values in the range of $20.58-23.02 \mathrm{MJ} / \mathrm{kg}$.

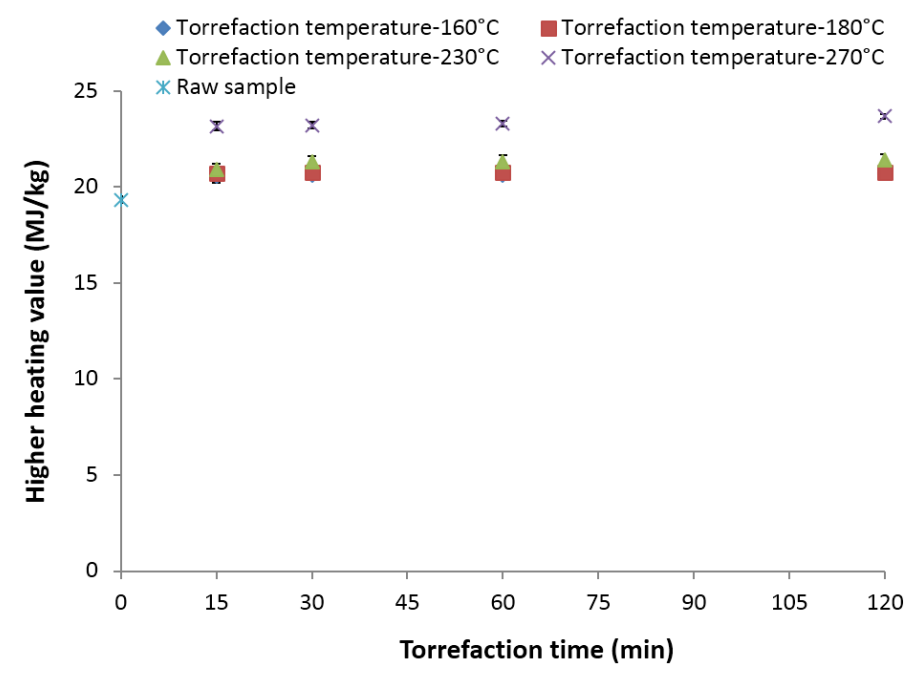

Figure 12. Higher heating value in the lodgepole pine grind with respect to the torrefaction time and temperature.

\section{Analysis of Variance and Multiple Regression Models}

The experimental data were further analyzed to understand the significance of the process variables, with respect to the proximate and ultimate composition and higher heating values. Multiple regression models were also developed for proximate, ultimate composition, and energy data. Table 4 shows the multiple regression equations fitted for the experimental data, and Table 5 indicates the significance of the process variables based on the ANOVA. The regression equations developed were found to be statistical significant at $p<0.001$. The regression equations indicated that in the case of proximate composition, the torrefaction temperature and residence time were positively correlated for fixed carbon and ash content, whereas for moisture and volatiles, there was a negative correlation. Furthermore, the regression equations indicated that the coefficient of torrefaction temperature was higher when compared to the torrefaction residence time. In the case of the ultimate composition, hydrogen, nitrogen, oxygen, sulfur, the $\mathrm{H} / \mathrm{C}$ ratio, and the $\mathrm{O} / \mathrm{C}$ ratio were negatively correlated, whereas in the case of carbon content and higher heating values, they are positively correlated with the torrefaction temperature and residence time.

ANOVA analysis indicates that the moisture content, ash content, and fixed carbon were influenced by both the torrefaction temperature and residence time at $p<0.001$. In the case of volatile content, the torrefaction temperature, at $p<0.001$, and not by residence time, had a significant effect. In the case of the ultimate composition, hydrogen content was influenced by torrefaction temperature at $p<0.001$, whereas residence time was found to be insignificant. Carbon, oxygen, and sulfur content were influenced by both torrefaction temperature and residence time at $p<0.001$, 
whereas nitrogen content was influenced by torrefaction time at $p<0.01$. The $\mathrm{H} / \mathrm{C}$ and $\mathrm{O} / \mathrm{C}$ ratios are influenced by the torrefaction temperature at $p<0.001$, whereas the residence time influenced the $\mathrm{H} / \mathrm{C}$ ratio at $p<0.05$ and not the $\mathrm{O} / \mathrm{C}$ ratio. In the case of a higher heating value, the torrefaction temperature was influenced at $p<0.001$, and the residence time was not significant.

Bates and Ghoniem [41] indicate that torrefaction temperatures of 250 and $300{ }^{\circ} \mathrm{C}$ and residence times of 15-60 min result in 16\%-30\% solid mass loss; increasing the residence time further results in an additional $42 \%-48 \%$ mass loss. They have concluded that mass loss is faster in the first stage of torrefaction, which is primarily attributable to the decomposition of hemicellulose (with an increasing contribution from cellulose decomposition at higher temperatures). The non-condensable products, such as $\mathrm{CO}_{2}$ and $\mathrm{CO}$, reach the peak value at residence times of $10 \mathrm{~min}$ and then start to decline. The same authors also indicate that the amount of methanol and lactic acid, which is produced during the decomposition of acetoxy- and methoxy-groups, increased up to $10 \mathrm{~min}$, and then it remained unchanged. The observations in this study indicate that the coefficient of torrefaction temperature is higher when compared to the torrefaction residence time. Additionally, the analysis of variance supports this observation, where torrefaction temperature has more significant impacts on the proximate and ultimate composition and its higher heating value when compared to torrefaction residence time. Nhuchhen [37] work on torrefaction of biomass indicate that the net effect of the residence time is not as prominent as the temperature; the same authors also concluded that in a rotary torrefaction system, the torrefaction temperature is more prominently impactful when compared to angular speed and the inclination of the dryer.

Table 4. Multiple regression equations for the chemical and energy properties.

\begin{tabular}{ccccc}
\hline S. No. & $\begin{array}{c}\text { Chemical Composition and } \\
\text { higher heating value }\end{array}$ & Multiple Regression Equation & $\begin{array}{c}\text { Coefficient of } \\
\text { Determination }\left(\mathbf{R}^{2}\right)\end{array}$ & Statistical Significance \\
\hline Proximate composition & & & \\
\hline 1 & Moisture content (\%, w.b.) & $\mathrm{y}=5.013-0.0124 \mathrm{x}_{1}-0.00515 \mathrm{x}_{2}$ & 0.93 & $p<0.001$ \\
2 & Ash (\%) & $\mathrm{y}=-0.2718+0.0066 \mathrm{x}_{1}+0.0029 \mathrm{x}_{2}$ & 0.93 & $p<0.001$ \\
3 & Volatiles (\%) & $\mathrm{y}=121.8021-0.2322 \mathrm{x}_{1}-0.0409 \mathrm{x}_{2}$ & 0.79 & $p<0.001$ \\
4 & Fixed carbon (\%) & $\mathrm{y}=-22.9741+0.2236 \mathrm{x}_{1}+0.0431 \mathrm{x}_{2}$ & 0.80 & $p<0.001$ \\
& Ultimate composition & $\mathrm{y}=9.4969-0.018 \mathrm{x}_{1}-0.0054 \mathrm{x}_{2}$ & 0.72 & $p<0.001$ \\
1 & Hydrogen (\%) & $\mathrm{y}=36.3531+0.09716 \mathrm{x}_{1}+0.0397 \mathrm{x}_{2}$ & 0.97 & $p<0.001$ \\
2 & Carbon (\%) & $\mathrm{y}=54.344-0.0800 \mathrm{x}_{1}-0.03478 \mathrm{x}_{2}$ & 0.96 & $p<0.001$ \\
3 & Oxygen (\%) & $\mathrm{y}=0.7163-0.00183 \mathrm{x}_{1}-0.00069 \mathrm{x}_{2}$ & 0.89 & $p<0.001$ \\
4 & Nitrogen (\%) & $\mathrm{y}=0.03492-0.000071 \mathrm{x}_{1}-0.000047 \mathrm{x}_{2}$ & 0.89 & $p<0.001$ \\
5 & Sulfur (\%) & $\mathrm{y}=2.158-0.004436 \mathrm{x}_{1}-0.00179 \mathrm{x}_{2}$ & 0.83 & $p<0.05$ \\
6 & H/C ratio & $\mathrm{y}=1.4845-0.0039 \mathrm{x}_{1}-0.00096 \mathrm{x}_{2}$ & 0.72 & $p<0.001$ \\
7 & O/C ratio & $\mathrm{y}=16.462+0.02321 \mathrm{x}_{1}+0.0026 \mathrm{x}_{2}$ & 0.82 & \\
8 & Higher heating value (MJ/kg) & & \\
\hline
\end{tabular}

Table 5. Analysis of variance for the chemical and energy properties.

\begin{tabular}{|c|c|c|c|}
\hline \multirow{2}{*}{ S. No. } & \multirow{2}{*}{$\begin{array}{l}\text { Chemical Composition and } \\
\text { higher heating value }\end{array}$} & \multicolumn{2}{|c|}{ Process Variables } \\
\hline & & Torrefaction Temperature $\left(\mathrm{x}_{1}\right)$ & Torrefaction Residence Time $\left(\mathrm{x}_{2}\right)$ \\
\hline \multicolumn{4}{|c|}{ Proximate composition } \\
\hline 1 & Moisture content (\%, w.b.) & $(-)^{* * *}$ & $(-)^{* * *}$ \\
\hline 2 & Ash (\%) & $(+)^{* * *}$ & $(+)^{* * *}$ \\
\hline 3 & Volatile content $(\%)$ & $(-)^{* * *}$ & ns \\
\hline 4 & Fixed carbon $(\%)$ & $(+)^{* * *}$ & $(+)^{* * *}$ \\
\hline \multicolumn{4}{|c|}{ Ultimate composition } \\
\hline 5 & Hydrogen $(\%)$ & $(-)^{* * *}$ & ns \\
\hline 6 & Carbon $(\%)$ & $(+)^{* * *}$ & $(+)^{* * *}$ \\
\hline 7 & Nitrogen $(\%)$ & $(-)^{* * *}$ & $(-)^{* *}$ \\
\hline 8 & Oxygen (\%) & $(-)^{* * *}$ & $(-)^{* * *}$ \\
\hline 9 & Sulfur (\%) & $(-)^{* * *}$ & $(-)^{* * *}$ \\
\hline 10 & $\mathrm{H} / \mathrm{C}$ ratio & $(-)^{* * *}$ & $(-)^{*}$ \\
\hline 11 & $\mathrm{O} / \mathrm{C}$ ratio & $(-)^{* * *}$ & ns \\
\hline 12 & Higher heating value (MJ / kg) & $(+)^{* * *}$ & ns \\
\hline
\end{tabular}




\section{Discussion}

The moisture content of lodgepole pine biomass reduces both at deep drying and torrefaction temperatures. If the target is to reduce the moisture content of the biomass, deep drying at 160 and $180{ }^{\circ} \mathrm{C}$ for $<30 \mathrm{~min}$ will help to reduce most of the moisture in the lodgepole pine. At deep drying temperature, the loss of moisture content can be due to dehydration reactions with less change to the chemical composition of the biomass. At higher torrefaction temperatures between $\geqslant 180$ and $\leqslant 350{ }^{\circ} \mathrm{C}$, the loss of moisture and volatiles can be due to the devolatilization and carbonization of hemicellulose and cellulose [24]. Bergman and Kiel [19] and Prins [42] report that drying and depolymerization occur between 225 and $325^{\circ} \mathrm{C}$ for hemicelluloses. According to Bridgeman et al. [24], the loss of moisture is due to the evaporation and dehydration reactions between the organic molecules, which result in the release of organic and inorganic products from the biomass. The organics that are typically released during torrefaction include sugars, poly-sugars, acids, alcohols, furans, and ketones [13]. The present study indicated that the change in the chemical composition at deep drying temperature (160 and $180^{\circ} \mathrm{C}$ ) is minimal compared to torrefaction temperatures of 230 and $270{ }^{\circ} \mathrm{C}$.

According to Tumuluru et al. [13], at deep drying temperatures of 160 and $180{ }^{\circ} \mathrm{C}$, the changes in the biomass are due to dehydration reactions, whereas at torrefaction temperature of $>230^{\circ} \mathrm{C}$, the major reactions are devolatilization and carbonization, causing significant changes in the chemical composition when compared to the raw material. Bates and Ghoniem [41], in their study, indicate that at a lower temperature of $200{ }^{\circ} \mathrm{C}$, the composition is similar to non-torrefied willow, whereas at an increased temperature, it will increase the mass fraction of carbon, while those of hydrogen and oxygen decrease. The authors' two-step model indicates that in the first stage, oxygenated species, such as water, acetic acid, and carbon dioxide, are released, and at the second stage, lactic acid, methanol, and acetic acid were released. Medic et al. [43], in their studies on the effects of torrefaction process parameters on biomass feedstock upgrading, conclude that corn stover undergoes changes in chemical composition and energy content during the torrefaction process. These authors also indicate that at higher torrefaction temperatures, the biomass can be characterized in several ways, such as a mass loss of up to $45 \%$, a decrease in the $\mathrm{O} / \mathrm{C}$ ratio from 1.11 to 0.6 , and an increase in the energy density of about $19 \%$.

Tumuluru et al. [13], in their review on the torrefaction of biomass, indicate that at $>250{ }^{\circ} \mathrm{C}$, the biomass undergoes extensive devolatilization and carbonization. These reactions result in the loss of volatiles and an increase in the carbon content. Furthermore, it is observed that the change in the ash content is related to the loss of other biomass components, such as moisture and volatiles. According to Park et al. [44], during torrefaction, volatile loss is due to thermal breakdown of carbohydrate fractions, which results in the accumulation of the residual ash after torrefaction. The same authors further indicate that these changes increase the fixed carbon content of the biomass. Ultimate composition data indicate that oxygen is reduced during torrefaction and the reduction is increased at higher torrefaction temperatures. In the present study, changes in hydrogen and oxygen were marginal at a lower temperature of $180{ }^{\circ} \mathrm{C}$, when compared to torrefaction temperatures of 230 and $270{ }^{\circ} \mathrm{C}$. This observation is corroborated with the findings of other researchers [13,45-47]. The decrease of oxygen content is mainly due to the dehydration reaction, which produces water vapor and releases $\mathrm{CO}$ and $\mathrm{CO}_{2}$. During torrefaction, the loss of volatiles, gases, and water also results in a decrease in hydrogen content. The decrease in oxygen and hydrogen content and the increase of carbon content (from approximately $51 \%-66 \%$ ), at a $270{ }^{\circ} \mathrm{C}$ torrefaction temperature and a 30 -min residence time, results in lowering the atomic $\mathrm{O} / \mathrm{C}$ ratio (from 0.63 to 0.31 ). According to Tumuluru et al. [46], torrefaction temperatures of $>300^{\circ} \mathrm{C}$ may not be needed, because there is a significant loss of higher energy content volatiles. Furthermore, it may increase the relative ash content of the biomass.

According to the van Krevelen diagram, the substantial change in the atomic ratio of carbon, hydrogen, and oxygen makes torrefied material act more like coal, making the torrefied material more suitable for co-firing applications. Lodgepole pine torrefied at $270{ }^{\circ} \mathrm{C}$ and at different residence times reduced the $\mathrm{H} / \mathrm{C}$ and $\mathrm{O} / \mathrm{C}$ ratios and moved them closer to high-quality coal, such as Powder River 
Basin and Illinois Basin coals. The lower $\mathrm{O} / \mathrm{C}$ ratio observed at higher torrefaction temperatures can be due to the release of oxygen-rich compounds (e.g., $\mathrm{CO}, \mathrm{CO}_{2}$, and $\mathrm{H}_{2} \mathrm{O}$ ), whereas lower $\mathrm{H} / \mathrm{C}$ ratios can be due to the formation of $\mathrm{CH}_{4}$ and $\mathrm{C}_{2} \mathrm{H}_{6}$ during torrefaction. The decrease of the $\mathrm{H} / \mathrm{C}$ and $\mathrm{O} / \mathrm{C}$ ratios with an increase in the torrefaction temperature and residence time results in fuels that produce less smoke, less water-vapor formation, and lower energy loss during the combustion and gasification processes [6].

The heating value of biomass is an important quality attribute for energy generation applications [2]. The increase in torrefaction temperature and residence time increases the calorific value (higher heating value), and higher temperatures and residence times result in the loss of more volatiles and increased energy density. The increase in the heating value is due to the decrease in moisture content and an increase of carbon content in the samples. Zanzi et al. [22] and Nimlos et al. [48], in their report, confirm that increasing the torrefaction temperature increases the higher heating value. Tumuluru et al. [12] indicate that at torrefaction temperatures of $>300^{\circ} \mathrm{C}$, there is a significant loss of higher energy content volatiles within the biomass.

The feedstock variable that impacts the proximate, ultimate, and energy properties of the torrefied material is the particle size used for torrefaction. Smaller particle sizes used in the present study might have been more reactive to torrefaction temperature due to the higher surface area. According to Nhuchhen [49] and Wang et al. [50], particle size impacts the devolatilization reactions. These authors further indicate that a smaller particle size results in a greater intra-particle effect and heat transfer. Another important torrefaction parameter that can impact the resolution of the experimental data is the ramp time. This can impact the torrefaction reaction kinetics of the various components, such as lignin, hemicellulose, and cellulose. Current studies indicate the torrefaction of ground lodgepole pine at $270^{\circ} \mathrm{C}$ and a $15-30-m i n$ residence time improves the chemical composition and the higher heating value, making lodgepole pine more suitable for bio-power generation.

\section{Conclusions}

The research presented was carried out to understand the effect of torrefaction temperature and residence time on the proximate composition, ultimate composition, and higher heating values of a 2-mm lodgepole pine grind. Based on this research the following conclusions are drawn:

- The changes in proximate and ultimate composition were marginal at deep drying temperatures of 160 and $180{ }^{\circ} \mathrm{C}$, whereas at torrefaction temperatures of 230 and $270{ }^{\circ} \mathrm{C}$, the changes were significant.

- Increasing the torrefaction temperature to $270{ }^{\circ} \mathrm{C}$ and the residence time to 30 min significantly decreases the moisture content, hydrogen content, and oxygen content and increases the carbon and heating value.

- At $270{ }^{\circ} \mathrm{C}$ and a 120 -min residence time, carbon content increases to $69.86 \%$, while oxygen and hydrogen content decrease to $28.24 \%$ and $3 \%$, whereas the volatile content decreases to $45.81 \%$.

- The H/C and O/C ratios of the raw samples are about 1.42 and 0.59 , whereas at $270{ }^{\circ} \mathrm{C}$ and $120 \mathrm{~min}$, the $\mathrm{H} / \mathrm{C}$ and $\mathrm{O} / \mathrm{C}$ ratio decreases to 0.56 and 0.47 .

- The changes in these chemical compositions are attributed to the devolatilization of hemicellulose, which will typically happen at torrefaction temperatures of $>200{ }^{\circ} \mathrm{C}$. These reactions result in the formation of water, carbon monoxide, and carbon dioxide and influence the hydrogen and carbon content of the biomass.

- The heating value increased from its initial value of about $19.41 \mathrm{MJ} / \mathrm{kg}$ to about $23.67 \mathrm{MJ} / \mathrm{kg}$ at $270{ }^{\circ} \mathrm{C}$ and a 120 -min residence time. At lower torrefaction temperatures of $160-180{ }^{\circ} \mathrm{C}$, the increase in the heating value is marginal. 
Acknowledgments: This work was supported by the DOE Office of Energy Efficiency and Renewable Energy under DOE Idaho Operations Office Contract DE-AC07-05ID14517. Accordingly, the U.S. Government retains and the publisher, by accepting the article for publication, acknowledges that the U.S. Government retains a nonexclusive, paid-up, irrevocable, worldwide license to publish or reproduce the published form of this manuscript or to allow others to do so, for U.S. Government purposes.

Conflicts of Interest: The author declare no conflict of interest.

\section{References}

1. Framework Convention on Climate Change (FCCC), United Nations. Adoption of the Paris Agreement. In Proceedings of the Conference of Parties, Twenty-First Session, Paris, France, 11 December 2015.

2. Arias, B.R.; Pevida, C.G.; Fermoso, J.D.; Plaza, M.G.; Rubiera, F.G.; Pis Martinez, J.J. Influence of torrefaction on the grindability and reactivity of woody biomass. Fuel Process. Technol. 2008, 89, 169-175. [CrossRef]

3. United Nations. Kyoto Protocol to the United Nations Framework Convention on Climate Change; United Nations: Kyoto, Japan, 1998; pp. 1-20.

4. U.S. Department of Energy. U.S. Billion-Ton Update: Biomass Supply for a Bioenergy and Bioproducts Industry; Perlack, R.D., Stokes, B.J., Eds.; U.S. Department of Energy, Oak Ridge National Laboratory: Oak Ridge, TN, USA, 2011; p. 227.

5. Tumuluru, J.S.; Tabil, L.G.; Song, Y.; Iroba, K.L.; Meda, V. Grinding energy and physical properties of chopped and hammer-milled barley, wheat, oat and canola straws. Biomass Bioenergy 2014, 60, 58-67. [CrossRef]

6. Tumuluru, J.S. Comparison of Chemical Composition and Energy Property of Torrefied Switchgrass and Corn Stover. Front. Energy Res. 2015, 3, 46. [CrossRef]

7. Tumuluru, J.S.; Searcy, E.; Kenney, K.L.; Smith, W.A.; Gresham, G.; Yancey, N. Impact of feedstock supply systems unit operations on feedstock cost and quality for bioenergy applications. In Valorization of lignocellulosic Biomass in a Biorefinery: From Logistic to Environmental and Performance Impact; Kumar, R., Singh, S., Balan, V., Eds.; Nova Science Publishers: New York, NY, USA, 2016.

8. Karki, B.; Muthukumarappan, K.; Wang, Y.J.; Dale, B.; Balan, V.; Gibbons, W.R.; Karunanithy, C. Physical characteristics of AFEX-pretreated and densified switchgrass, prairie cord grass, and corn stover. Biomass Bioenergy 2015, 78, 164-174. [CrossRef]

9. Lynam, J.G.; Reza, M.T.; Vasquez, V.R.; Coronella, C.J. Pretreatment of rice hulls by ionic liquid dissolution. Bioresour. Technol. 2012, 114, 629-636. [CrossRef] [PubMed]

10. Reza, M.T.; Lynam, J.G.; Uddin, M.H.; Coronella, C.J. Hydrothermal carbonization: Fate of inorganics. Biomass Bioenergy 2013, 49, 86-94. [CrossRef]

11. Singh, S.; Cheng, G.; Sathitsuksanoh, N.; Wu, D.; Varanasi, P.; George, A.; Balan, V.; Gao, X.; Kumar, R.; Dale, B.E.; et al. Comparison of different biomass pretreatment techniques and their impact on chemistry and structure. Front. Energy Res. 2015, 2, 1-12. [CrossRef]

12. Tumuluru, J.S.; Hess, J.R.; Boardman, R.D.; Wright, C.T.; Westover, T.L. Formulation, pretreatment, and densification options to improve biomass specifications for co-firing high percentages with coal. Ind. Biotechnol. 2012, 8, 113-132. [CrossRef]

13. Tumuluru, J.S.; Sokhansanj, S.; Hess, J.R.; Wright, C.T.; Boardman, R.D. A review on biomass torrefaction process and product properties for energy applications. Ind. Biotechnol. 2011, 7, 384-401. [CrossRef]

14. Sarkar, M.; Kumar, A.; Tumuluru, J.S.; Patil, K.N.; Bellmer, D.D. Gasification performance of switchgrass pretreated with torrefaction and densification. Appl. Energy 2014, 127, 194-201. [CrossRef]

15. Yang, Z.; Sarkar, M.; Kumar, A.; Tumuluru, J.S.; Huhnke, R.L. Effects of torrefaction and densification on switchgrass pyrolysis products. Bioresour. Technol. 2014, 174, 266-273. [CrossRef] [PubMed]

16. Hoover, A.N.; Tumuluru, J.S.; Teymouri, F.; Moore, J.; Gresham, G. Effect of pelleting process variables on physical properties and sugar yields of ammonia fiber expansion pretreated corn stover. Bioresour. Technol. 2014, 164, 128-135. [CrossRef] [PubMed]

17. Ray, A.E.; Hoover, A.N.; Nagle, N.; Chen, X.; Gresham, G.L. Effect of pelleting on the recalcitrance and bioconversion of dilute-acid pretreated corn stover under low- and high-solids conditions. Biofuels 2013, 4, 271-284. [CrossRef]

18. Aston, J.E.; Tumuluru, J.S.; Lacey, J.A.; Thompson, D.N.; Thompson, V.S.; Fox, S. Alkaline deacetylation of corn stover: Effects on feedstock quality. In Proceedings of the 2015 AICHE Annual Meeting, Salt Lake City, UT, USA, 8-13 November 2015. 
19. Bergman, P.C.A.; Kiel, J.H.A. Torrefaction for Biomass Upgrading. ECN-RX-05-180. In Proceedings of the 14th European Biomass Conference \& Exhibition, Paris, France, 17-21 October 2005.

20. Fonseca, F.F.; Luengo, C.A.; Bezzon, G.; Soler, P.B. Bench unit for biomass residues torrefaction. In Proceedings of the Conference on Biomass for Energy and Industry, Würzburg, Germany, 8-11 June 1998.

21. Tumuluru, J.S.; Hess, J.R. New market potential: Torrefaction of woody biomass. Available online: http:/ / www.iom3.org/materials-world-magazine/feature/2015/jun/02/new-market-potentialtorrefaction-woody-biomass (accessed on 27 February 2016).

22. Zanzi, R.; Ferro, D.T.; Torres, A.; Soler, P.B.; Bjornbom, E. Biomass torrefaction. In Proceedings of the 6th Asia-Pacific International Symposium on Combustion and Energy Utilization, Kuala Lumpur, Malaysia, 20-22 May 2002.

23. Chen, W.H.; Kuo, P.C.E. A study on torrefaction of various biomass materials and its impact on lignocellulosic structure simulated by a thermogravimetry. Energy 2010, 35, 2580-2586. [CrossRef]

24. Bridgeman, T.G.; Jones, J.M.; Shield, I.; Williams, P.T. Torrefaction of reed canary grass, wheat straw and willow to enhance solid fuel qualities and combustion properties. Fuel 2008, 87, 844-856. [CrossRef]

25. Johnston, D.C. Estimating Lodgepole Pine Biomass. Theses, Dissertations, Professional Papers, Paper 2237, Missoula, MT, USA, 1977. Available online: http:/ / scholarworks.umt.edu/etd (accessed on 1 June 2016).

26. Parisa, Z.; Sokhansanj, S.; Bi, X.; Lim, S.J.; Mani, S.; Melin, S.; John, K. Density, heating value, and composition of pellets made from Lodgepole Pine (Pinus concorta Douglas) infested with mountain pine beetle (Dendroctonus ponderosae Hopkins). Can. Biosyst. Eng. 2008, 50, 3.47-3.55.

27. Backlund, I. Cost-effective Cultivation of Lodgepole Pine for Biorefinery Applications. In Faculty of Forest Sciences Department of Forest Biomaterials and Technology; Swedish University of Agricultural Sciences Umeå: Uppsala, Switzerland, 2013.

28. Bridgewater, A.V.; Czernik, S.; Piskorz, J. An overview of fast pyrolysis. In Progress in Thermochemical Biomass Conversion; Blackwell Science Ltd.: Oxford, UK, 2001; pp. 977-997.

29. ASTM Standard D3173-86, A. Standard Test Method for Moisture in the Analysis Sample of Coal and Coke; ASTM International: West Conshohocken, PA, USA, 1996; Available online: http:/ / www.astm.org/DATABASE. CART/HISTORICAL/D3173-87R96.htm (accessed on 6 January 2016).

30. ASTM Standard D3174, A. Standard Test Method for Ash in the Analysis Sample of Coal and Coke from Coal; ASTM International: West Conshohocken, PA, USA, 2002; Available online: http:/ /www.astm.org/Standards / D3174 (accessed on 6 January 2016).

31. ASTM Standard D3175, A. Standard Test Method for Volatile Matter in the Analysis Sample of Coal and Coke; ASTM International: West Conshohocken, PA, USA, 2007; Available online: http://www.astm.org/Standards/ D3175 (accessed on 6 January 2016).

32. ASTM Standard D3178, A. Standard Test Methods for Carbon and Hydrogen in the Analysis Sample of Coal and Coke; ASTM International: West Conshohocken, PA, USA, 2002; Available online: http:/ /www.astm.org/ Standards/D3178.htm (accessed on 6 January 2016).

33. ASTM Standard D3179, A. Standard Test Methods for Nitrogen in the Analysis Sample of Coal and Coke; ASTM International: West Conshohocken, PA, USA, 2002; Available online: https://www.astm.org/Standards / D3179.htm (accessed on 6 January 2016).

34. ASTM Standard D3177, A. Standard Test Methods for Total Sulfur in the Analysis Sample of Coal and Coke; ASTM International: West Conshohocken, PA, USA, 2007; Available online: http://www.astm.org/Standards / D3177.htm (accessed on 6 January 2016).

35. ASTM Standard D5865-10a., A.S. Standard Test Method for Gross Calorific Balue of Coal and Coke; ASTM International: West Conshohocken, PA, USA, 2010; Available online: http://www.astm.org/Standards / D5864-10a (accessed on 6 January 2016).

36. Branca, C.; di Blasi, C.; Galgano, A.; Brostrom, M. Effects of the Torrefaction Conditions on the Fixed-Bed Pyrolysis of Norway Spruce. Energy Fuel. 2014, 28, 5882-5891. [CrossRef]

37. Nhuchhen, D.R.; Basu, P.; Acharya, B. Torrefaction of poplar in a continouus two-stage, indirectly heated totary torrefier. Energy Fuel 2016, 30, 1027-1038.

38. Carter, C.L.; Abdoulmoumine, N.; Kulkarni, A.; Adhikari, S.; Fasina, O. Physicochemical properties of thermally treated biomass and energy requirement for torrefaction. ASABE 2013, 53, 1093-1100. 
39. Dutta, A. Torrefaction and Other Processing Options; Guelph, U.O., Ed.; University of Guelph: Guelph, ON, Canada, 2011; Available online: http://www.ofa.on.ca/uploads/userfiles/files/animesh\%20dutta.pdf (accessed on 24 February 2016).

40. Peng, J.H.; Bi, H.T.; Sokhansanj, S.; Lim, J.C. A study of particle size effect on biomass torrefaction and densification. Energy Fuel 2012, 26, 3826-3839. [CrossRef]

41. Bates, R.B.; Ghoniem, A.F. Biomass torrefaction: Modeling of volatile and solid product evlution kinetics. Bioresour. Technol. 2012, 124, 460-469. [CrossRef] [PubMed]

42. Prins, M.J. Thermodynamic Analysis of Biomass Gasification and Torrefaction; Technische Universiteit Eindhoven: Eindhoven, The Netherlands, 2005.

43. Medic, D.; Darr, M.; Shah, A.; Potter, B.; Zimmerman, J. Effects of torrefaction process parameters on biomass feedstock upgrading. Fuel 2012, 91, 147-154. [CrossRef]

44. Park, J.; Meng, J.; Lim, K.H.; Rojas, O.J.; Park, S. Transformation of lignocellulocis biomass during torrefaction. J. Anal. Appl. Pyrolysis 2013, 100, 199-206. [CrossRef]

45. Poudel, J.; Oh, S.C. A kinetic analysis of wood degradation in supercritical alcohols. Ind. Eng. Chem. Res. 2012, 51, 4509-4514. [CrossRef]

46. Tumuluru, J.S.; Boardman, R.D.; Wright, C.T.; Hess, J.R. Some chemical compositional changes in Miscanthus and white oak sawdust samples during torrefaction. Energies 2012, 5, 3928-3947. [CrossRef]

47. Tumuluru, J.S.; Boardman, R.D.; Wright, C.T. Response surface analysis of elemental composition and energy properties of corn stover during torrefaction. J. Biobased Mater. Bioenergy 2012, 6, 25-35. [CrossRef]

48. Nimlos, M.; Brooking, E.; Looker, M.J.; Evans, R.J. Biomass torrefaction studies with a molecular beam mass spectrometer. Am. Chem. Soc. 2003, 48, 590.

49. Nhuchhen, D.R. Studies on Advanced Means of Biomass Torrefaction; Dalhousie University: Halifaxm, NS, Canada, 2016.

50. Wang, M.J.; Huang, Y.F.; Chiueh, P.T.; Kuan, W.H.; Lo, S.L. Microwave-induced torrefaction of rice husk and sugarcane residues. Energy 2012, 37, 177-184. [CrossRef]

(C) 2016 by the author; licensee MDPI, Basel, Switzerland. This article is an open access article distributed under the terms and conditions of the Creative Commons Attribution (CC-BY) license (http:/ / creativecommons.org/licenses/by/4.0/). 